\title{
Sistem Kendali Eddy Current Brakes Dinamometer menggunakan Linear Quadratic Regulator (LQR)
}

\section{MUHAMMAD ARROFIQ ${ }^{1}$, LUKMAN SIDIQ NUGROHO², FAHMIZAL ${ }^{3}$, ESA APRIASKAR ${ }^{4}$}

1,2,3 Departemen Teknik Elektro dan Informatika, Sekolah Vokasi, Universitas Gadjah Mada, Indonesia

4Jurusan Teknik Elektro, Fakultas Teknik, Universitas Negeri Semarang, Indonesia Email: rofiq@ugm.ac.id

Received 4 Juni 2021 | Revised 6 Juli 2021 | Accepted 9 Juli 2021

\begin{abstract}
ABSTRAK
Makalah ini memberikan analisis perbandingan antara teknik kendali klasik yaitu kendali PID dengan teknik kendali modern pada sistem Eddy current brakes dinamometer. Eddy current brakes merupakan sistem pengereman modern yang membutuhkan sebuah sistem kendali untuk menunjang kinerja pengereman. Selama ini kendali PID lebih sering digunakan, namun di beberapa kondisi dinilai kurang optimal. Dengan demikian, diperlukan pengembangan kendali yang modern dan optimal yaitu full state feedback Linear Quadratic Regulator (LQR). Perbandingan respon waktu pengereman disimulasikan menggunakan Matlab/Simulink. Hasil simulasi menunjukkan respon waktu pengereman pada kendali $L Q R$ lebih baik dibandingkan dengan kendali PID, dengan Ts = 2.12 detik, $\mathrm{Tr}=1.18$ detik, dan tanpa overshoot. Adapun kendali PID, meskipun menghasilkan $T s=0.27$ detik dan $\mathrm{Tr}=0.18$ detik, namun demikian masih terdapat overshoot sebesar $0.7 \%$.
\end{abstract}

Kata kunci: Eddy brakes, PID, LQR, Matlab

\begin{abstract}
This paper provides a comparative analysis between PID control as a classical control technique and modern control technique in the dinamometer Eddy current brakes system. Eddy current brakes is a modern braking system that requires a control system to support the braking performance. PID control is often used to be implemented but in some conditions it is less optimal. Therefore, it is necessary to develop a modern and optimal control, such as a full state feedback Linear Quadratic Regulator (LQR). The comparison of the braking time responses were simulated using Matlab/Simulink. The simulation results show that the response of $\angle Q R$ control is better than the PID, with $T s=2.12$ seconds, $T r=1.18$ seconds, and without overshoot. On the other side, PID control, although having Ts $=0.27$ seconds and $\operatorname{Tr}=0.18$ seconds, there is still an overshoot about $0.7 \%$.
\end{abstract}

Keywords: Eddy brakes, PID, LQR, Matlab 
Arrofiq, dkk

\section{PENDAHULUAN}

Perkembangan sektor otomotif khususnya di Indonesia berkembang cukup pesat dalam beberapa dekade ini, khususnya pada sektor mesin kendaraan. Dalam dunia otomotif setiap mesin memiliki karakteristik dan kemampuan yang berbeda mulai dari tenaga mesin, torsi mesin, dan emisi bahan bakar mesin tersebut. Oleh karena itu digunakanlah dinamometer sebagai alat yang dapat memberikan informasi karakteristik dari sebuah mesin. Alat tersebut dapat digunakan untuk menganalisis performa mesin lebih lanjut. Secara umum, terdapat dua tipe percobaan yang dilakukan untuk mendapatkan performa mesin yaitu constant brakes testing dan maximum brakes testing (Nahari, dkk, 2012). Guna mendukung kinerja pengereman dinamometer yang optimal, maka digunakanlah sistem Eddy current brakes dinamometer.

Eddy current brakes dinamometer dipilih karena mampu memberikan laju perubahan beban yang cepat, memiliki pengereman yang baik pada kecepatan yang tinggi, kondisi yang cepat, stabil dan akselerasi yang mudah dikendalikan. Sehingga menjadikan Eddy current brakes dinamometer ini sangat fleksibel dan ideal untuk pengujian performa mesin dibandingkan dengan dinamometer inersia (Nunes \& Brojo, 2020). Sistem Eddy current brakes dinamometer memanfaatkan arus yang ditimbulkan oleh adanya perubahan fluks magnetis pada piringan konduktor sebagai pemicu untuk menciptakan gaya pengereman pada pengetesan performa mesin (Cho, dkk, 2017). Parameter waktu, besarnya gaya pengereman, dan kestabilan sistem saat pengereman merupakan parameter yang dianalisis untuk mendapatkan kinerja Eddy current brakes dinamometer yang optimal.

Untuk mendapatkan kinerja respon waktu pengereman yang sesuai kriteria, maka diperlukan desain sistem kendali yang optimal. Desain kendali yang masih umum digunakan dalam industri adalah kendali klasik PID. Beberapa pertimbangan pemanfaatan metode kendali ini adalah karena mudah dan fleksibel untuk dirancang dan diimplementasikan (Apriaskar, dkk, 2019)(Munadi, dkk, 2020). Namun kendali PID dalam beberapa kondisi dinilai belum optimal dalam mengendalikan plant seperti Eddy current brakes dinamometer. Beberapa penelitian yang berkaitan dengan pemanfaatan kendali PID, umumnya mengarah pada optimasi tuning parameter kendali (Alkhafaji, dkk, 2018)(Rao, dkk, 2020). Namun demikian, untuk menghasilkan suatu sistem kendali yang optimal, pengendali yang berbasis full state feedback juga dapat digunakan.

Dalam beberapa kasus pengendali berbasis full state feedback memiliki respon yang lebih baik jika dibandingkan dengan pengendali PID. Sebagaimana penelitian yang dilakukan oleh (Ma'arif \& Setiawan, 2021), menggunakan metode kendali integral state feedback untuk studi kasus pengendalian motor DC. Pada penelitian tersebut, pengujian dilakukan secara implementasi menggunakan embedded system Arduino. Hasil pengujian menunjukkan pengendali yang berbasis full state feedback memiliki respon yang lebih baik dari pada PID karena waktu yang dibutuhkan untuk mencapai nilai referensi lebih cepat. Penelitian terkait lain dilakukan oleh (Handaya \& Fauziah, 2021) yang membandingkan performa pengendali PID dan full state feedback Linear Quadratic Regulator (LQR) untuk kontrol posisi motor DC. Pada penelitian tersebut pengendali LQR memiliki performa yang lebih baik, khususnya dari sisi kriteria settling time dan overshoot yang lebih kecil. Perbandingan antara PID dan LQR juga telah dilakukan oleh (Houari, dkk, 2020) untuk studi kasus kontrol pada tilt rotor airplane. Penelitian tersebut juga menghasilkan hasil yang positif untuk pengendali LQR dilihat dari kriteria overshoot dan response time. Oleh karena itu, peggunaan pengendali LQR untuk sistem Eddy current brakes dinamometer sebagai pengembangan desain kendali kearah yang lebih modern layak untuk diuji guna mendapatkan respon waktu pengereman yang optimal. 
Makalah ini membahas simulasi perancangan kendali pada sistem Eddy current brakes dinamometer menggunakan metode kendali LQR. Simulasi dibangun menggunakan software Matlab. Model sistem Eddy current brakes yang digunakan adalah dalam bentuk state space. Pengamatan respon sistem dengan dan tanpa pengendali menggunakan fitur Simulink pada Matlab. Dari hasil pengamatan respon tersebut, kemudian dilakukan analisis terhadap perbandingan hasil respon antara menggunakan kendali klasik PID dengan kendali optimal LQR.

\section{MODEL SISTEM}

Eddy current brakes dengan kemampuan pengereman menggunakan komponen elektromekanikal yang dapat dikatakan sebagai sistem pengereman yang lebih modern dibandingkan dengan sistem pengereman secara mekanik (Gulbahce, dkk, 2013). Sistem pengereman menggunakan Eddy current brakes dinamometer memberikan kecepatan pengereman yang lebih responsif pada kondisi kecepatan yang tinggi, lebih awet karena tidak melibatkan komponen mekanik yang memerlukan perawatan khusus, dan model Eddy current brakes dinamometer sangat mudah untuk dikendalikan menggunakan berbagai jenis kendali (Brin, 2013). Struktur dari model Eddy current brakes terdiri dari bagian piringan konduktor yang berputar dan bagian coil yang dialiri arus atau permanen magnet untuk menciptakan medan magnet pada bagian piringan konduktor (Chen, dkk, 2019). Jika dilihat berdasarkan strukturnya Eddy current brakes dibagi menjadi empat bagian seperti pada Gambar 1, dengan keterangan sebagai berikut: (1) core dan exciting coil, (2) celah tanpa udara, (3) piringan besi dan (4) sisi luar piringan besi.

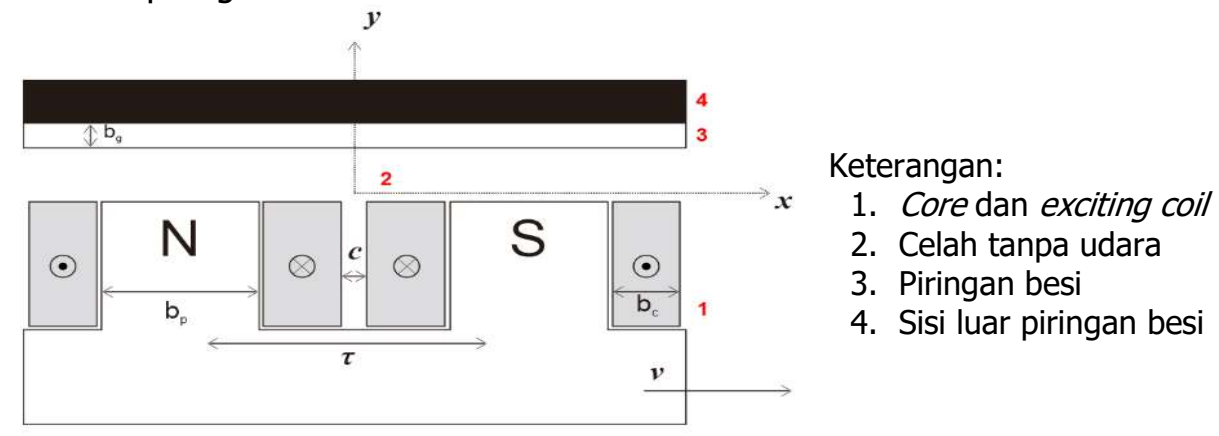

\section{Gambar 1. Model Dua Dimensi Sistem Eddy Current Brakes}

Sistem kinerja dari Eddy current brakes dinamometer adalah ketika disc piringan besi yang terhubung dengan shaft mesin berputar dan diberikan input gaya pengereman sistem akan mendeteksi besarnya gaya pengereman melalui sensor Load cell. Sensor ini berfungsi sebagai pendeteksi besarnya gaya pengereman yang dikonversi dalam bentuk sinyal analog, kemudian sinyal tersebut menjadi variabel yang akan dideteksi oleh mikrokontroller. Setelah feedback dari load cell data diproses pada mikrokontroller untuk dilihat kestabilan respon pengereman sistem.

Eddy current merupakan arus yang muncul akibat adanya perubahan fluks magnetik yang terjadi pada sebuah konduktor (Nahari, dkk, 2012), dimana konduktor merupakan iron disk dengan diameter $10 \mathrm{~cm}$ yang terintegrasi dengan shaft pada sebuah mesin (dinamo). Menurut hukum Lenz, Eddy current menciptakan medan magnet yang arahnya berlawanan dengan perubahan medan magnet yang menciptakannya. Oleh karena itu, Eddy current dimanfaatkan sebagai gaya pengereman dinamometer $(\mathrm{Fb})$. Gaya $\mathrm{Fb}$ ini muncul diantara vektor medan magnet dan Eddy current. 
Dalam kondisi kecepatan rendah putaran piringan besi induksi magnetik menyebabkan Eddy current sangat kecil sehingga dapat diabaikan dikarenakan induksi magnetis hampir tegak lurus terhadap piringan besi. Pada kondisi kecepatan menengah akan menghasil gaya pengereman yang lebih besar dibandingkan sebelumnya sehingga induksi pada kutub < B0 (induksi magnetik awal). Pada kondisi kecepatan tinggi mengakibatkan induksi pada kutub dari Eddy current > B0 sehingga nilai induksi magnetik awal dapat diabaikan.

Skema desain Eddy current brakes ditunjukkan pada Gambar 2, dengan beberapa parameter yang disajikan pada Tabel 1. Berdasarkan pemodelan sistem, total gaya pengereman Eddy current brakes diformulasikan seperti pada Persamaan (1).

$$
F=\int_{g}^{g+e} d z \int_{0}^{2} d \theta \int_{\text {Rinner }}^{\text {Router }} \Delta F_{\theta} r d r
$$

Tabel 1. Parameter Desain Sistem Eddy Current Brakes

\begin{tabular}{|c|c|}
\hline Parameter & Nilai \\
\hline Ketebalan disk $(d)$ & $1 \mathrm{~cm}$ \\
\hline Kecepatan sudut $(\omega)$ & $3000 \mathrm{RPM}$ \\
\hline Jarak disk dan pole $(x)$ & $0.5 \mathrm{~m}$ \\
\hline
\end{tabular}

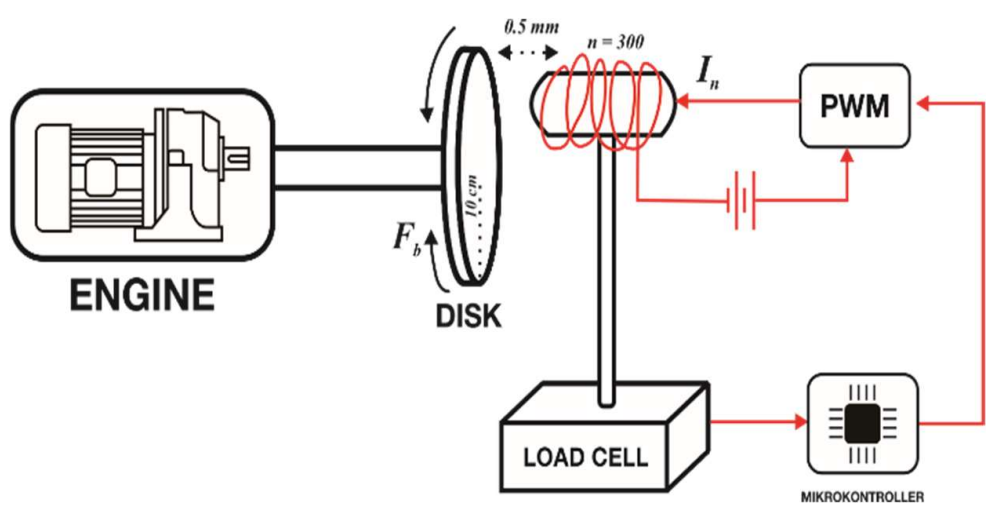

\section{Gambar 2. Skema Desain Eddy Current Brakes Dinamometer}

Persamaan (2) dan (3) merupakan hasil penyelesaian persamaan gaya pengereman total pada Eddy current brakes. Dengan $F$ adalah gaya pengereman $(\mathrm{N}), D$ adalah elektromagnetik pole diameter $(\mathrm{m})$, d adalah disk thickness $(\mathrm{cm}), B$ adalah induksi magnetik (Tesla), cadalah faktor proportional, $\omega$ adalah kecepatan sudut (RPM), $x$ adalah jarak disk dan pole (m) dan $R$ adalah disk radius $(\mathrm{m})$.

$$
\begin{gathered}
F=0.25 \frac{\pi}{4} D^{2} d B^{2} c \omega \\
c=0.5\left[1-\frac{0.25}{\left(1+\frac{\pi}{R}\right)^{2}\left(\frac{R-x}{D}\right)^{2}}\right]
\end{gathered}
$$

Dari semua spesifikasi dapat ditemukan persamaan hubungan antara arus (I) dengan gaya pengereman (F) seperti pada Persamaan (4). Desain pemodelan sistem Eddy current brakes dinamometer yang direpresentasikan dalam bentuk state space dan fungsi alih berdasarkan 
penurunan dari Persamaan (2)-(3) menjadi Persamaan (5) untuk pemodelan state space dan fungsi alih pada pada Persamaan (6).

$$
\begin{gathered}
I=2.106 \ln (F)+5.288 \\
\&(t)=\left[\begin{array}{cc}
-2.029 & -2.826 \\
4 & 0
\end{array}\right]\left[\begin{array}{l}
x_{1} \\
x_{2}
\end{array}\right]+\left[\begin{array}{l}
2 \\
0
\end{array}\right] u(t) ; \quad y=\left[\begin{array}{ll}
0 & 1.413
\end{array}\right] x(t) \\
G_{(s)}=\frac{11.304}{s^{2}+2.029 s+11.304}
\end{gathered}
$$

Melalui pemodelan dengan menggunakan state space dan fungsi alih dapat dianalisis respon sistem gaya pengereman secara open loop untuk mendapatkan karakteristik transien respon sistem awal sebelum merancang desain kendali menggunakan PID ataupun LQR. Model open loop dalam bentuk state space dari sistem Eddy current brakes dinamometer yang direpresentasikan pada blok Simulink ditunjukkan pada Gambar 3. Tujuan analisis dari kedua jenis pengendali PID dan LQR adalah untuk membandingkan respon sistem yang paling optimal untuk mencapai kriteria respon sistem.

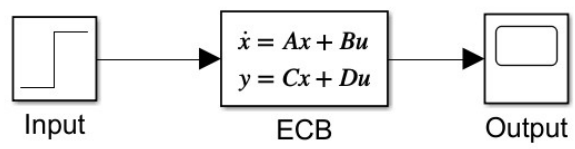

Gambar 3. Blok Simulink Sistem Eddy Current Brakes Dinamometer Open Loop

\section{PERANCANGAN SISTEM KENDALI}

Setelah didapatkan karakteristik dalam kondisi open loop maka, dilakukan perancangan kendali PID dan LQR. Perancangan kendali dilakukan dengan berdasarkan penerapan teori kajian literatur sebagai dasar perancangan kendali sistem Eddy current brakes dinamometer pada simulasi Matlab/Simulink, berikut ini merupakan dasar persamaan yang digunakan untuk perancangan kendali.

\subsection{Kendali Proporsional Integral Derivatif (PID)}

Kendali proporsional, integral dan derivatif (PID) merupakan tipe kendali yang digunakan umumnya pada sistem single input dan single output (SISO). Sistem kendali tersebut akan membandingkan sinyal kesalahan (error) dengan sinyal masukan (set point) dengan menggunakan parameter proporsional, integral dan derivatif (Isdaryani, dkk, 2021). Kendali PID secara konvensional dibedakan menjadi dua tipe yaitu dependent pada Persamaan (7) dan independent pada Persamaan (8). Jika dinyatakan dalam fungsi alih dalam domain $s$ menjadi pada Persamaan (9)-(10). Dengan $u$ adalah output controller, $e$ adalah nilai kesalahan, $K_{p}$ adalah proportional constant, $K_{i}$ adalah integral constant dan $K_{d}$ adalah derivative constant.

$$
\begin{gathered}
u(t)=K_{p}\left[e(t)+\frac{1}{\tau_{i}} \int e(t) d t+\tau_{d} \frac{d}{d t} e(t)\right] \\
u(t)=\left[K_{p} e(t)+K_{i} \int e(t) d t+K_{d} \frac{d}{d t} e(t)\right] \\
u(s)=K_{p}\left[1+\frac{1}{\tau_{i} s}+\tau_{d} s\right] e(s) \\
\text { ELKOMIKA }-927
\end{gathered}
$$




$$
u(s)=\left[K_{p}+\frac{K_{i}}{s}+K_{d} s\right] e(s)
$$

Pencarian parameter konstanta $K_{p}, K_{i}$ dan $K_{d}$ untuk pengendali PID mengadaptasi dari rumus Ackermann pole placement pada Persamaan (12) dengan persamaan karakteristik pada Persamaan (11).

$$
\begin{gathered}
\left|s I-A+B K_{a}\right|=\left(s-\mu_{1}\right)\left(s-\mu_{2}\right) \ldots\left(s-\mu_{n}\right)=s^{n}+\alpha_{1} s^{n-1}+\ldots+\alpha_{n-1} s+\alpha_{n} \\
K_{a}=\left[\begin{array}{lllll}
0 & 0 & \ldots & 0 & 1
\end{array}\right]\left[\begin{array}{c}
B \\
A B \\
\ldots \\
A^{n-1} B
\end{array}\right] \phi(A)
\end{gathered}
$$

Dimana $\phi(A)$ adalah $\phi(A)=A+\alpha_{1} A^{n-1}+\cdots+\alpha_{n-1} A+\alpha_{n} I$, dan nilai gain full state feedback $K_{a}$ pada Persamaan (12) adalah sebagaimana yang ditunjukkan pada Persamaan (13). Dengan $\widehat{K}$ untuk menemukan parameter $K_{p_{r}} K_{i}$ dan $K_{d}$ adalah sebagaimana yang terdapat pada Persamaan (14).

$$
\begin{gathered}
K_{a}=\left[\begin{array}{cc}
C & 0 \\
C A & C B \\
C A^{2} & C A B
\end{array}\right] K \\
K=\left[\begin{array}{c}
K_{p} \\
K_{i} \\
K_{d}
\end{array}\right]=\left(1-K_{a} C B\right)^{-1}\left[\begin{array}{c}
K_{p} \\
K_{i} \\
K_{d}
\end{array}\right]
\end{gathered}
$$

Gambar 4 menunjukkan diagram blok state space pada Simulink untuk pengendalian plant sistem Eddy current brakes dinamometer dengan menggunakan kendali PID. Sehingga perlu dilakukan pembuatan persamaan sistem augmented seperti pada Persamaan (15).

$$
\begin{aligned}
& x_{a}^{\&}=A_{a} x_{a}+B_{a} u_{a} \\
& A_{a}=\left[\begin{array}{ll}
A & B \\
0 & 0
\end{array}\right], \quad B_{a}=\left[\begin{array}{l}
0 \\
1
\end{array}\right], \quad u_{a}=K_{a} x_{a}, \quad x_{a}=\left[\begin{array}{l}
x \\
u
\end{array}\right]
\end{aligned}
$$

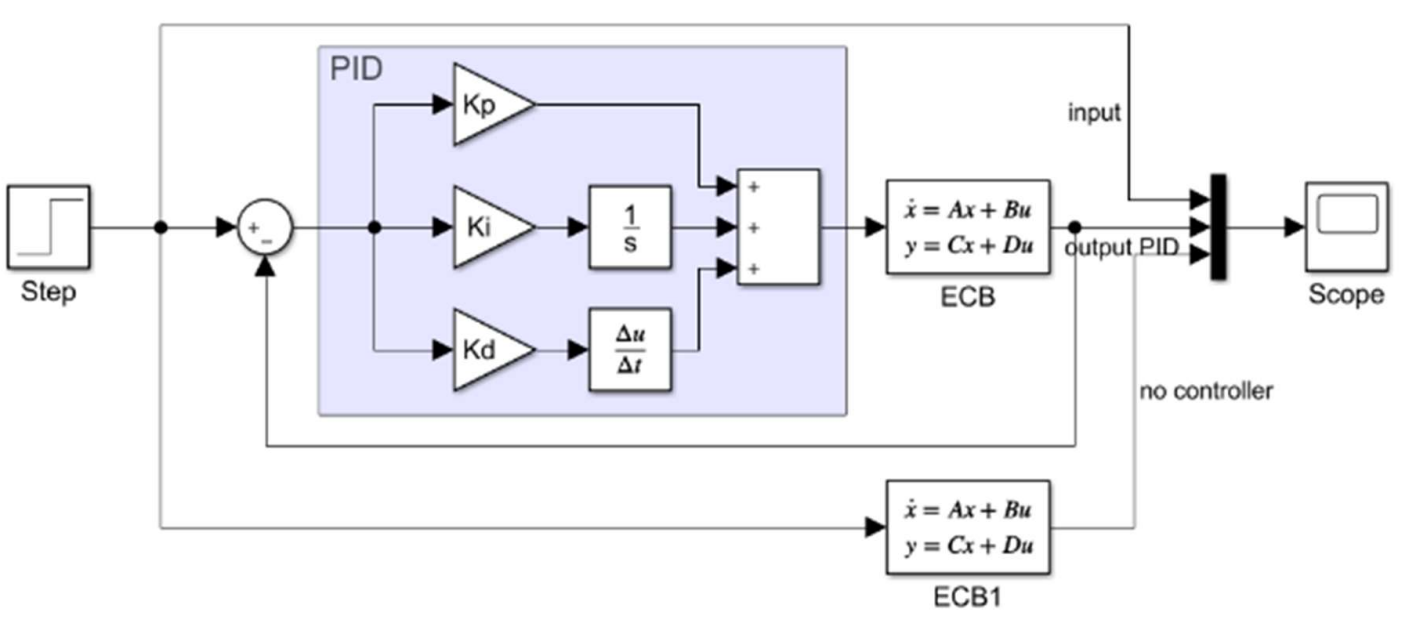

Gambar 4. Blok Simulink Sistem Eddy Current Brakes Dinamometer dengan Kendali PID ELKOMIKA - 928 


\subsection{Kendali Linear Quadratic Regulator(LQR)}

Kendali Linear Quadratic Regulator (LQR) merupakan optimalisasi sistem dengan representasi state space. LQR memiliki struktur yang sama dengan pole placement yaitu menggunakan full state feedback, akan tetapi perbedaan antara LQR dan pole placement adalah bagaimana menentukan matriks $K$ sebagai gain feedback (Fahmizal, dkk, 2019). Diagram blok kendali sistem full state feedback LQR pada sistem Eddy current brakes dinamometer disajikan pada Gambar 5.

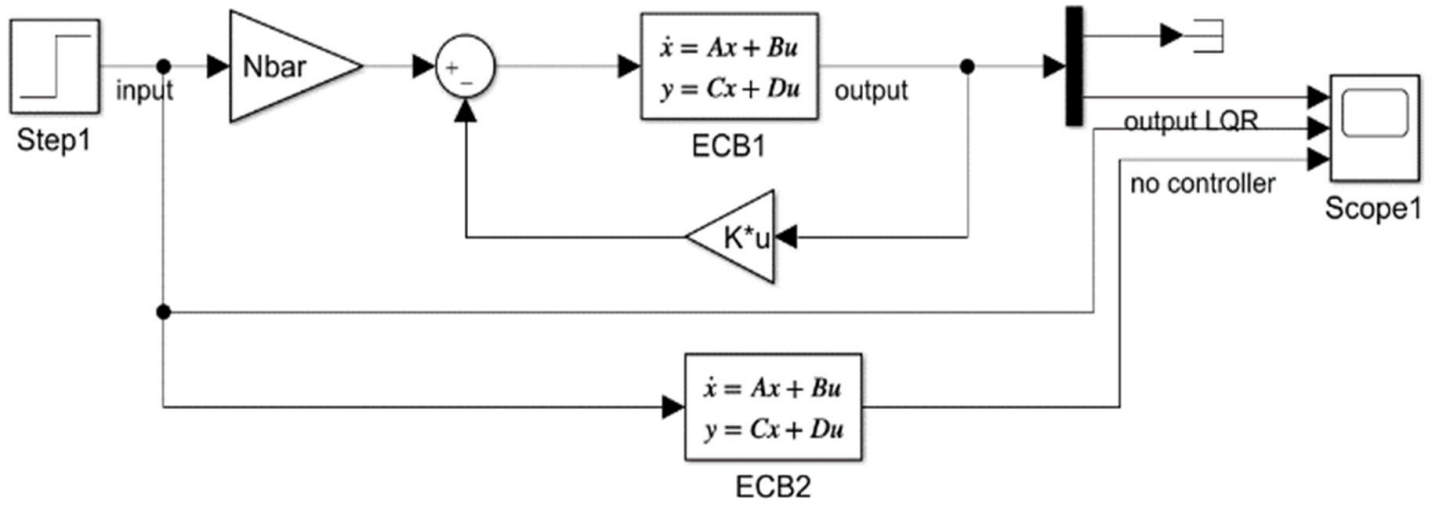

\section{Gambar 5. Blok Simulink Sistem Eddy Current Brakes Dinamometer dengan Kendali LQR}

Pada kendali pole placement memiliki kelemahan dalam pencarian matriks gain $K$ yang digunakan untuk memindahkan pole sistem menuju ke pole yang diinginkan. Kelemahan tersebut merujuk pada aspek effort sistem yang seringkali tidak diperhatikan. Sehingga berakibat pada konsumsi energi kinerja aktuator yang tinggi pada saat berusaha untuk menstabilkan respon sistem. Melalui kendali LQR permasalahan tersebut dapat diselesaikan dengan menggunakan matriks gain $K$ yang diperoleh dari matriks $Q$ dan $R$ pada konsep sistem kendali LQR. Sistem kendali LQR memiliki kemampuan untuk mengoptimalkan matriks gain $K$ dengan mempertimbangkan faktor performance dan effort sistem dengan mengoptimalkan indeks performansi sistem (Purnawan, dkk, 2017). Indeks performansi yang optimal didapatkan dengan meminimalkan nilai indeks performansi pada Persamaan (16).

$$
J=\int_{0}^{\infty}\left(x^{T} Q x+u^{T} R u\right) d t
$$

Melalui Persamaan (16) terdapat matriks $Q$ real simetris yang merupakan positif definit (atau positif semidefinit) dan matriks $R$ real simetris yang merupakan positif definit. Matriks $Q$ digunakan untuk mengatur performa dari sistem sehingga berhubungan dengan vektor state sistem, sedangkan matriks Q berpengaruh pada nilai steady state error pada tanggapan sistem, semakin besar nilai Q maka semakin kecil nilai steady state error. Matriks $R$ digunakan untuk memodifikasi setiap state input pada sistem untuk mencapai gain yang diinginkan, hal ini akan berpengaruh pada efisiensi kinerja actuator untuk menstabilkan sistem. Matriks $R$ akan berperan untuk mengendalikan setiap state input pada sistem guna mengatur tingkat efisiensi effort suatu actuator. Melalui persamaan indeks performansi dapat dihitung nilai gain $K$ dengan persamaan sebagaimana yang ditunjukkan pada Persamaan (17). Matriks $P$ merupakan penyelesaian dari persamaan Riccati yang direpresentasikan pada Persamaan (18).

$$
\begin{gathered}
K=R^{-1} B^{T} P \\
A^{T} P+P A-P B R^{-1} B^{T} P+Q=0
\end{gathered}
$$


Namun, adapun syarat yang harus dipenuhi sebelum merancang desain kendali menggunakan LQR adalah sistem harus bersifat controllable. Itu artinya sinyal masukan $u$ dapat mengontrol dinamika dari setiap state vector variable $x$. Apabila sinyal masukan $u$ tidak dapat mengendalikan dinamika setiap state-nya akan berakibat pada pengaturan dinamika state menggunakan matriks $Q$ yang tidak dapat mengatur performance dan matriks $R$ yang tidak dapat mengatur effort dari sistem. Sifat controllability dapat diketahui dengan menggunakan pengujian controllability matriks $\left(C_{M}\right)$ seperti pada Persamaan (19). Apabila rank $n$ dari controllability matriks menunjukkan hasil yang sama dengan orde sistem maka dapat dikatakan sistem adalah fully controllable.

$$
C_{M}=\left[\begin{array}{lllll}
B & A B & A^{2} B & \ldots & A^{n-1} B
\end{array}\right]
$$

\subsection{Desain Kendali Zero Steady State Error}

Hasil dari perancangan kendali full state feedback dengan metode LQR menghasilkan respon transien yang akan sesuai dengan kriteria yang diinginkan, akan tetapi terdapat permasalahan pada steady state error response. Masalah ini merupakan selisih antara respon input dengan output sistem dalam waktu yang tidak terhingga. Respon input yang dimaksud ini adalah masukan dari sistem closed loop, atau dalam istilah lain disebut nilai referensi atau set point. Analisis zero steady state error dilakukan setelah diketahui bahwa sistem sudah mencapai kestabilan. Analisis tersebut digunakan untuk memperbaiki errorsistem agar mencapai kondisi zero steady state error yang artinya sudah tidak terdapat error dalam kondisi steady state. Terdapat beberapa metode analisis zero steady state erroryaitu menggunakan gain reference input non feedback mengunakan $\operatorname{Nbar}(\bar{N})$ dan atau menggunakan integral control $\left(K_{e}\right)$.

Namun pada pembahasan perancangan kendali LQR Eddy current brakes dinamometer ini menggunakan steady state error dengan gain reference input $\operatorname{Nbar}(\bar{N})$ yang nantinya akan menghasilkan respon sistem yang zero steady state error ketika diberikan input sinyal step. Sehingga struktur desain sistem kendali dapat digambarkan seperti pada Gambar 5 yang dinotasikan dengan gain $\bar{N}$. Nilai penguatan dapat dihitung dengan Persamaan (20) dan (21), atau dengan Persamaan (22) sebagai persamaan sinyal kendali. Kemudian dapat diperoleh penguatan $\bar{N}$ pada Persamaan (23).

$$
\begin{gathered}
{\left[\begin{array}{l}
N_{x} \\
N_{u}
\end{array}\right]=\left[\begin{array}{ll}
A & B \\
C & D
\end{array}\right]^{-1}\left[\begin{array}{l}
0 \\
1
\end{array}\right]} \\
u=-K x+\left(N_{u}+K N_{x}\right) r \\
u=-K x-\bar{N} r \\
\bar{N}=N_{u}+K N_{x}
\end{gathered}
$$

Dari semua perhitungan secara teoritical mulai dari pemodelan sistem, perancangan desain kendali PID dengan menentukan parameter $K_{p}, K_{i}$ dan $K_{d}$ yang diadaptasi dari persamaan Ackerman pole placement, kemudian perancangan kendali LQR dengan menentukan matriks $Q$ dan matriks $R$ untuk menentukan full state feedback gain $\mathrm{K}$ dan untuk mencapai kondisi zero steady state error menggunakan gain reference input dilakukan dengan komputasi pada Matlab. Hasil komputasi kemudian disimulasikan untuk setiap implementasi kendali PID maupun LQR pada sistem Eddy currrent brakes menggunakan Simulink. 


\section{HASIL DAN PEMBAHASAN}

Simulasi perancangan sistem kendali pada sistem Eddy current brakes dinamometer dilakukan menggunakan Matlab/Simulink untuk melihat respon waktu pengereman. Adapaun tujuan dari perancangan sistem kendali ini adalah agar kriteria respon mencapai sebagai berikut: (1) nilai overshoot kurang dari 10\%, (2) nilai settling time kurang dari 5 detik, (3) nilai rise time kurang dari 4 detik, dan tercapainya zero steady state error.

\subsection{Pengujian Sistem Tanpa Pengendali}

Pengujian sistem tanpa pengendali dilakukan dengan memberi masukan sistem berupa sinyal step sebesar 5 Newton $(\mathrm{N})$, sehingga menghasilkan respon waktu pengereman seperti pada Gambar 6. Hasil simulasi menunjukkan nilai gaya pengereman sebesar $6.85 \mathrm{~N}$ yang melebihi nilai input $5 \mathrm{~N}$ artinya mengalami overshoot dan menghasilkan transien respon sistem dengan nilai settling time 3.34 detik, rise time 0.394 detik dan overshoot sebesar $1.85 \mathrm{~N}$ atau $36.9 \%$. Nilai settling time dan rise time sudah cukup baik, namun perlu dilakukan perbaikan untuk nilai overshoot agar sesuai dengan spesifikasi yang diharapkan.

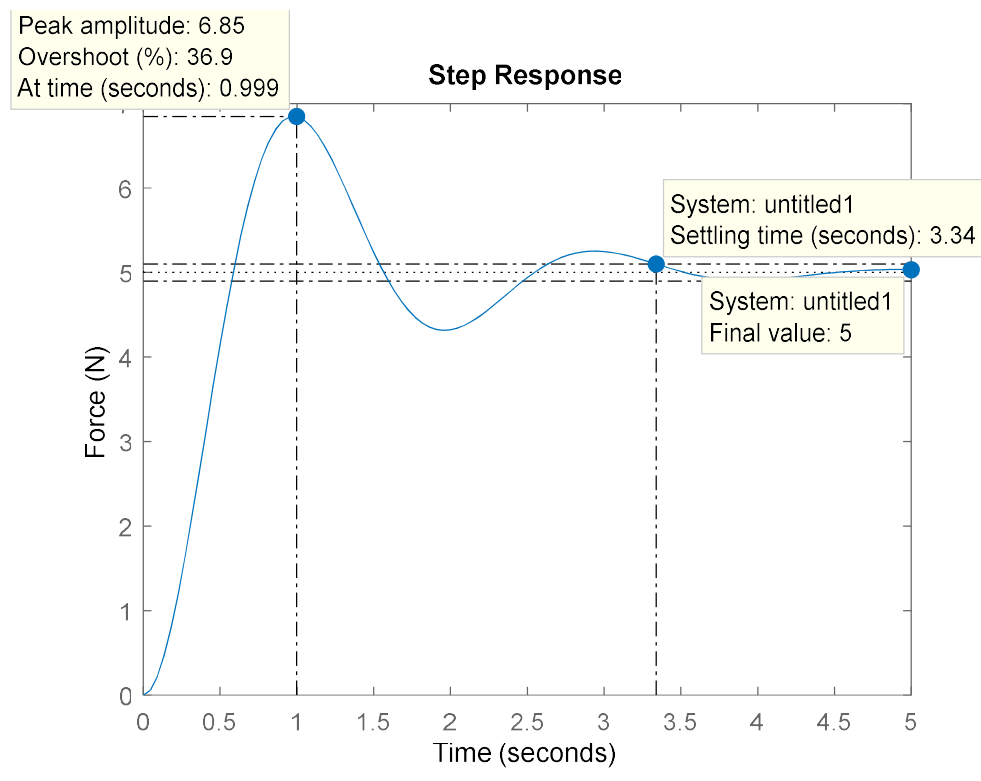

\section{Gambar 6. Hasil Pengujian Sistem Tanpa Pengendali (Open Loop)}

\subsection{Eigen value dan pole-zero map}

Melihat dari respon sistem open loop yang masih memiliki overshoot, pencarian nilai eigen value digunakan untuk melihat nilai kestabilan dari sistem yang dimodelkan dalam bentuk state space. Hasil perhitungan nilai eigen value sistem dapat diperoleh dengan menggunakan Persamaan (24) dengan hasil sebagaimana yang tercantum pada Persamaan (25).

$$
\begin{gathered}
\operatorname{det}(\lambda I-A)=0 \\
\lambda=\left[\begin{array}{cc}
-1.0145+3.2054 i & 0 \\
0 & -1.0145-3.2054 i
\end{array}\right]
\end{gathered}
$$

Diperoleh bahwa pole sistem berada pada $(-1.0145-3.2054 \mathrm{i},-1.0145+3.2054 \mathrm{i})$ daerah negatif yang artinya sistem Eddy current brakes tergolong sistem yang stabil. Namun pada sistem ini diperlukan adanya desain kendali yang dapat mengurangi nilai overshoot pada sistem sesuai 
dengan kriteria rancangan. Desain kendali yang diuji pada penelitian ini menggunakan kendali PID dan LQR.

\subsection{Hasil Pengujian Pengendali PID}

Penentuan parameter $K_{p}, K_{i}$ dan $K_{d}$ pada pengendali PID mengadaptasi dari Ackermann pole placement dengan langkah pertama yaitu menentukan persamaan karakteristik berdasarkan Persamaan (12) dari pole yang akan ditentukan. Kendali PID membutuhkan tiga parameter, sementara sistem hanya memiliki dua pole, sehingga diperlukan penambahan satu pole untuk memunculkan pole dominan yang ditempatkan pada lokasi paling kiri. Sehingga sistem akhir memiliki tiga pole yang terbentuk dari sistem augmented baru seperti pada Persamaan (15). Kemudian nilai $K_{p}, K_{i}$ dan $K_{d}$ dapat dicari dengan sistem augmented tersebut.

Nilai $K_{a}$ gain full state feedback dicari dengan Persamaan (13), atau dapat dengan menggunakan perintah "acker" pada Matlab. Setelah didapatkan nilai $K_{a}$ maka dapat diperoleh nilai $\widehat{K}$ dari Persamaan (14), melalui nilai $\widehat{K}$ tersebut didapatkan nilai $K_{p}, K_{i}$ dan $K_{d}$. Melalui semua perhitungan tersebut dengan asumsi lokasi pole terbaik [-1 -5.2 -999] dengan menggunakan perhitungan Matlab didapatkan nilai $K_{p}=459.5541, K_{i}=547.3900$ dan $K_{d}=$ 88.7448. Setelah didapatkan nilai parameter PID kemudian disimulasikan respon sistem menggunakan Simulink dengan model sistem dalam bentuk state space seperti pada Gambar 4 yang menghasilkan respon sistem Eddy current brakes dengan input gaya pengereman $5 \mathrm{~N}$ menggunakan kendali PID seperti pada Gambar 7.

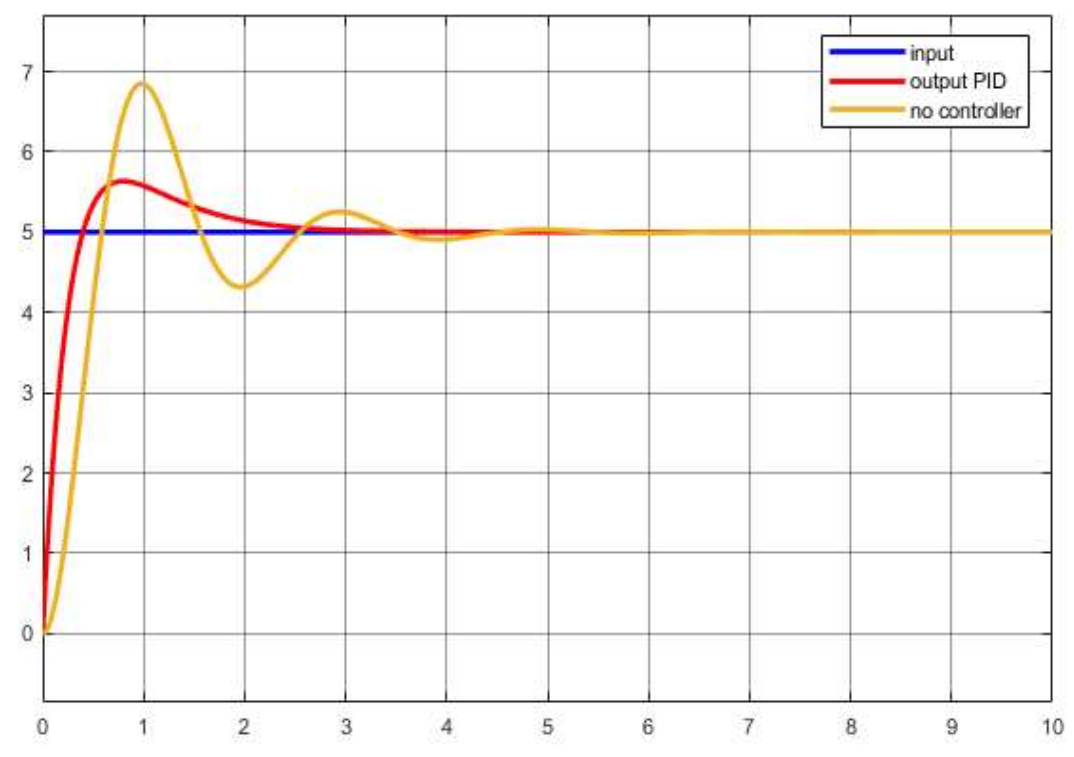

\section{Gambar 7. Hasil Pengujian Sistem dengan Pengendali PID}

Berdasarkan respon sistem pada Gambar 7 didapatkan nilai settling time(Ts) sekitar 0.27 detik yang masih tergolong sesuai dengan kriteria yaitu kurang dari 5 detik. Namun nilai tersebut sangat tidak realistis dikarenakan respon sistem pada kondisi riil tidak memungkinkan dengan waktu kurang dari 1 detik. Begitu juga untuk nilai rise time (Tr) yang ada di sekitar 0.18 detik. Selain itu, setelah dikendalikan menggunakan kendali PID masih didapatkan nilai overshoot sebesar $0.7 \%$. Hasil tersebut menunjukkan bahwa penggunaan pengendali PID menghasilkan respon sistem yang dapat mencapai kestabilan sesuai dengan kriteria, meskipun mengalami peningkatan gain yang cukup signifikan dengan gain sekitar $5.7 \mathrm{~N}$ dalam waktu kurang dari 1 detik. Oleh karena itu dilakukan percobaan dengan pengendali LQR sebagai pembanding. 


\subsection{Hasil Pengujian Pengendali LQR}

Pada pengujian sistem dengan pengendali LQR diawali dengan menentukan Matriks diagonal $Q$ untuk mengatur performance sistem dan matriks diagonal $R$ untuk mengatur input sistem yang nantinya digunakan untuk mendapatkan gain full state feedback matriks $K$ berdasarkan Persamaan (17). Dengan bantuan Matlab perhitungan tersebut dapat dilakukan dengan menggunakan perintah "lar()".

Namun sebelum dilakukan perancangan kendali LQR dilakukan pengecekan terharap controllability dari sistem menggunakan Matriks controllability sebagaimana yang ditunjukkan pada Persamaan (19). Dari pengecekan tersebut, kemudian dihasilkan nilai rank untuk Matriks controllability adalah 2 . Nilai tersebut menunjukkan bahwa semua variable state pada sistem Eddy current brakes bersifat fully controllable atau dapat dikendalikan secara menyeluruh karena nilai rankdari matriks sama dengan orde sistem. Perhitungan gain Kmelalui Persamaan (17) dari penyelesaian Persamaan (18) dengan nilai matriks $Q$ dan $R$ pada pengujian pertama sebagaimana yang terlihat pada Persamaan (26).

$$
Q=\left[\begin{array}{ll}
1 & 0 \\
0 & 1
\end{array}\right], \quad R=1
$$

Dari pengujian pertama menghasilkan nilai penguatan gain $K=\left[\begin{array}{ll}0.8025 & 0.3181\end{array}\right]$. Penambahan gain reference input yang dihitung berdasarkan Persamaan (20), (21), (22), dan (23) didapatkan nilai penguatan sebesar 1.2251. Setelah didapatkan nilai gain reference input untuk mencapai zero steady state response, maka dilakukan pengujian respon sistem Eddy current brakes dengan kendali LQR menggunakan Matlab. Pengujian respon Eddy current brakes menggunakan Simulink dengan model dalam bentuk state space seperti pada Gambar 5 menghasilkan respon waktu pengereman seperti pada Gambar 8.

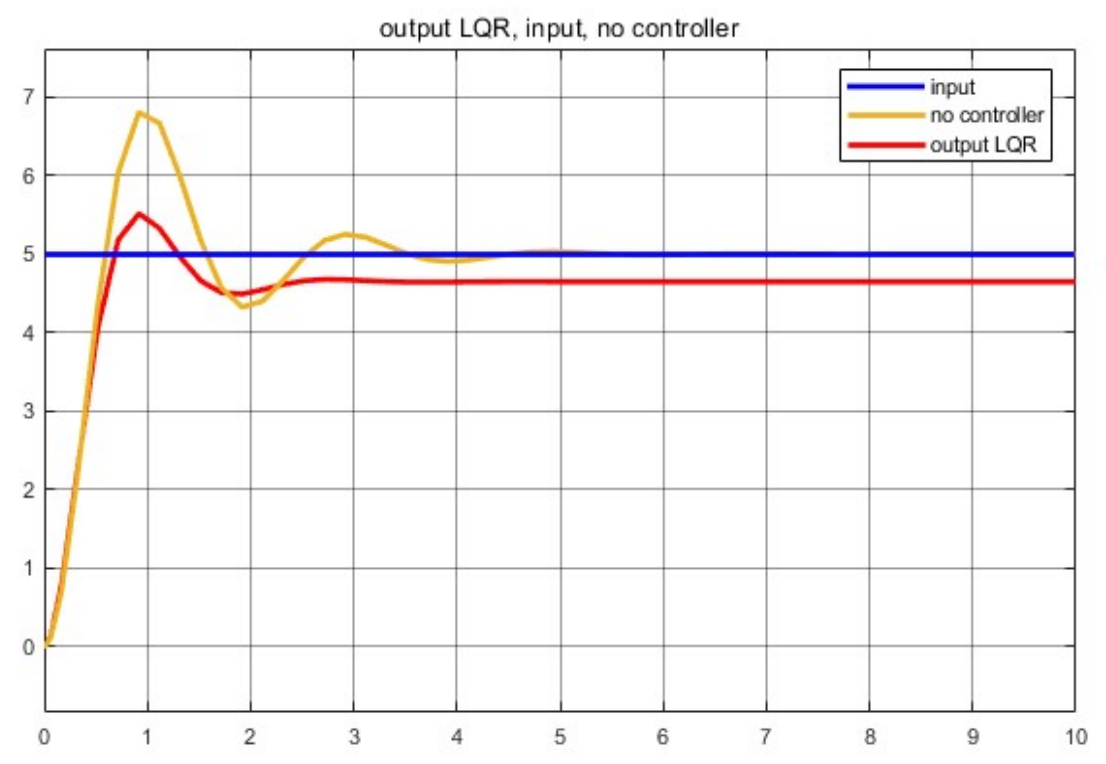

Gambar 8. Hasil Pengujian Pertama menggunakan Pengendali LQR

Berdasarkan hasil respon pada Gambar 8, penggunaan nilai Matriks $Q$ dan R pada pengujian pertama menghasilkan respon sistem yang stabil pada $4.61 \mathrm{~N}$ dan terdapat overshoot sebesar $0.5 \%$ dengan nilai input $5 \mathrm{~N}$. Hal tersebut menunjukkan bahwa dengan Matriks $Q$ dan $R$ pada pengujian pertama belum memenuhi kriteria overshoot sistem $0 \%$. Nilai settling time (Ts) 
sebesar 2.19 detik sudah baik dikarenakan masih dibawah batas kriteria 5 detik dan masih sesuai dengan kondisi riil. Dari percobaan pertama diperlukan perbaikan nilai pada Matriks $Q$ dan $R$ untuk dapat menaikkan respon ke $5 \mathrm{~N}$ dan memperbaiki nilai presentase overshoot menjadi $0 \%$.

Pada pengujian kedua, dilakukan modifikasi nilai Matriks $Q$ dan $R$ sebagaimana yang ditunjukkan pada Persamaan (27), yang kemudian diperoleh nilai gain $K=$ [2.7815 0.0117]. Selanjutnya, nilai gain Nbar $\bar{N}$ diperoleh sebesar 1.0083

$$
Q=\left[\begin{array}{cc}
40 & 0 \\
0 & 0.1
\end{array}\right], \quad R=3
$$

Setelah dilakukan modifikasi, didapatkan grafik respon sebagaimana yang ditunjukkan pada Gambar 9. Dari respon tersebut, terlihat setelah dilakukan perbaikan Matriks $Q$ dan $R$ serta gain reference input $\bar{N}$ sebagai precompensation terlihat hasil respon sistem dapat mencapai kestabilan dengan nilai gaya pengereman $5 \mathrm{~N}$ tanpa adanya overshoot. Nilai settling time(Ts) mencapai 2.12 detik yang sudah memenuhi kriteria dan nilai rise time (Tr) pada 1.18 detik yang juga masih sesuai dengan kriteria yang telah ditentukan. Penambahan $\bar{N}$ mampu meningkatkan gain output sistem, sehingga sesuai dengan nilai referensi dan mencapai kondisi zero steady state error. Dari hasil pengujian kedua menggunakan pengendali LQR ditambah dengan gain reference input $\bar{N}$ mampu memberikan respon waktu pengereman yang sesuai dengan kriteria.

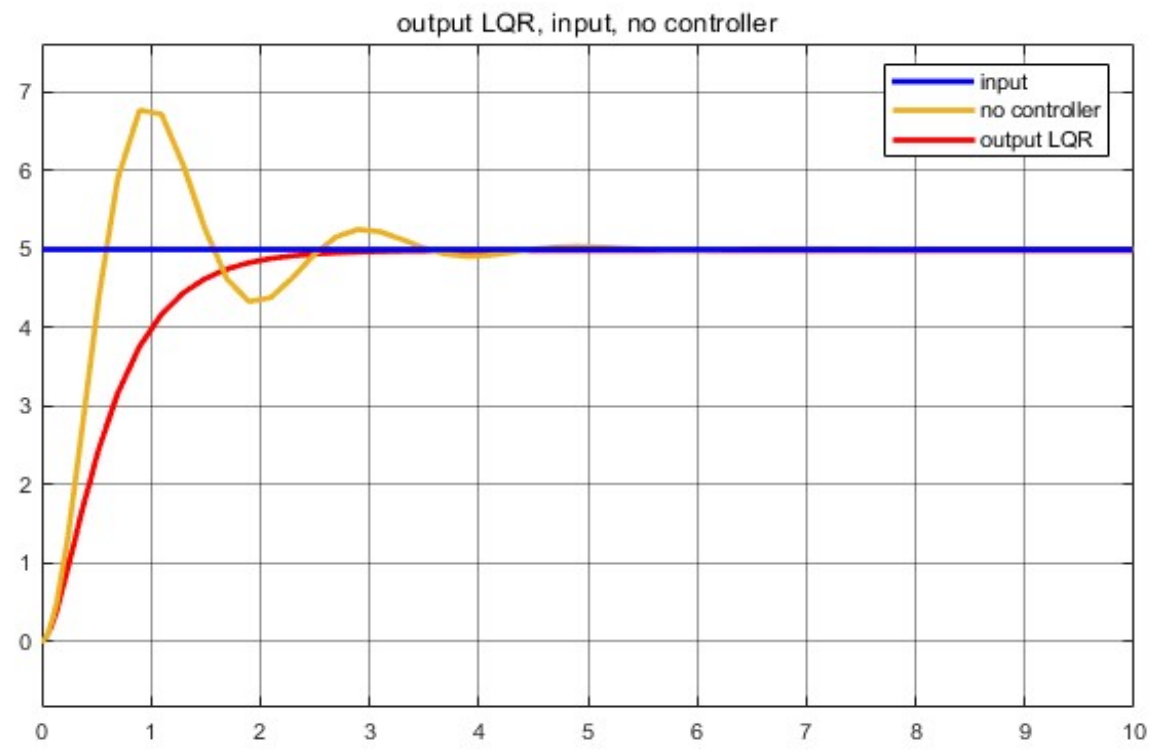

Gambar 9. Hasil Pengujian Kedua menggunakan Pengendali LQR

\subsection{Perbandingan Respon Sistem Kendali PID dan LQR}

Tabel 2 menunjukkan bahwa dengan menggunakan kendali LQR dapat menghasilkan respon waktu pengereman Eddy current brakes yang lebih baik dibandingkan dengan menggunakan kendali PID, hal ini dikarenakan dengan menggunakan kendali LQR memiliki hasil transient response yang sesuai dengan kriteria dengan nilai settling time $(\mathrm{Ts})<5$ detik dan rise time $(\mathrm{Tr})<4$ detik yang masih dapat dikatakan reasonable apabila diimplementasikan. 
Tabel 2. Perbandingan Respon Pengendali PID dan LQR

\begin{tabular}{|c|c|c|}
\hline Kriteria & PID & LQR \\
\hline Settling time & $0.27 \mathrm{~s}$ & $2.12 \mathrm{~s}$ \\
\hline Rise time & $0.18 \mathrm{~s}$ & $1.18 \mathrm{~s}$ \\
\hline$\%$ Overshoot & 0.7 & 0 \\
\hline Steady state error & 0 & 0 \\
\hline $\mathrm{F}_{\mathrm{b}}$ (Gaya Pengereman) & $5 \mathrm{~N}$ & $5 \mathrm{~N}$ \\
\hline
\end{tabular}

Dari hasil pengamatan respons sistem, penggunaan kendali LQR dapat dikatakan lebih optimal sebagai pengendali pada sistem Eddy current brakes dikarenakan dengan menggunakan full state feedback LQR mampu mengatur performance untuk dinamika setiap state vector sistem dengan menggunakan matriks $Q$ dan mengatur efisiensi kinerja aktuator melalui state vector input sistem menggunakan matriks $R$, sehingga dapat menghasilkan respon sistem yang lebih optimal dengan transient response yang sesuai dengan kriteria.

\section{KESIMPULAN}

Sistem Eddy current brakes dengan menggunakan kendali PID menghasilkan transient response yang sangat cepat meliputi dari nilai settling time $(\mathrm{Ts})=0.27$ detik dan rise time $(\mathrm{Tr})=0.18$ detik, serta adanya overshoot $0.7 \%$ di luar kriteria sistem. Respon tersebut dapat dikatakan kurang optimal dalam implementasi pada sistem Eddy current brakes, dikarenakan membutuhkan effort yang sangat tinggi dalam mengendalikan respons gaya pengereman dengan waktu yang sangat cepat sehingga berakibat pada borosnya konsumsi energi untuk menstabilkan gaya pengereman dan jika diimplentasikan ke sisi hardware akan tidak optimal karena respon waktu pengereman yang terlalu cepat. Adapun kelemahan pada pengendalian sistem menggunakan kendali PID menggunakan parameter $K_{p}, K_{i}$ dan $K_{d}$ yaitu belum mampunya mengendalikan setiap dinamika variable state yang diinginkan pada sistem Eddy current brakes. Berbeda dengan kendali full state feedback LQR yang dapat dikatakan tepat dan optimal untuk diimplementasikan pada sistem Eddy current brakes yang mampu menghasilkan respon waktu yang sesuai dengan kriteria settling time $(T s)=2.12$ detik dan rise time $(\mathrm{Tr})=0.18$ detik tanpa adanya overshoot sehingga waktu pengereman diberikan jeda 2 detik yang dapat menjadikan konsumsi energi controller untuk mengendalikan Eddy current brakes lebih efisien. Hal tersebut, dikarenakan kendali LQR mampu mengatur performance sistem dan mengatur efisiensi kinerja aktuator terhadap input sistem, dan kendali full state feedback memiliki metode untuk menghilangkan steady state error melalui tambahan gain reference input yang dapat menghasilkan respon sistem lebih optimal dengan transient response yang sesuai dengan kriteria respon waktu pengereman. Dengan demikian jenis kendali LQR sebagai kendali modern dapat menjadi pilihan pertimbangan pengembangan metode kendali klasik PID yang masih sering digunakan pada sistem Eddy current brakes untuk memperoleh kinerja gaya pengereman yang lebih optimal dan efisiensi energi dalam pengendalian gaya pengereman yang lebih baik.

\section{UCAPAN TERIMA KASIH}

Penulis mengucapkan terima kasih kepada Laboratorium Instrumentasi dan Kendali Departemen Teknik Elektro dan Informatika Sekolah Vokasi Universitas Gadjah Mada atas dukungan yang telah diberikan kepada penulis. 


\section{DAFTAR RUJUKAN}

Alkhafaji, F. S. M., Hasan, W. Z. W., Isa, M. M., \& Sulaiman, N. (2018). A novel method for tuning PID controller. Journal of Telecommunication, Electronic and Computer Engineering, 10(1-12), 33-38.

Apriaskar, E., Fahmizal, F., Salim, N. A., \& Prastiyanto, D. (2019). Performance Evaluation of Balancing Bicopter using P, PI, and PID Controller. Jurnal Teknik Elektro, 11(2), 44-49.

Brin, W. (2013). Design and Fabrication of an Eddy Current Brake Dynamometer for Efficiency Determination of Electric Wheelchair Motors [Wright State University].

Chen, C., Xu, J., \& Wu, X. (2019). Analytical Calculation of Braking Force of Super-High Speed Maglev Eddy Current Braking System. 2019 22nd International Conference on Electrical Machines and Systems (ICEMS), (pp. 1-5).

Cho, S., Liu, H.-C., Ahn, H., Lee, J., \& Lee, H.-W. (2017). Eddy Current Brake With a TwoLayer Structure: Calculation and Characterization of Braking Performance. IEEE Transactions on Magnetics, 53(11), 1-5.

Fahmizal, F., Arrofiq, M., Adrian, R., \& Mayub, A. (2019). Robot Inverted Pendulum Beroda Dua (IPBD) dengan Kendali Linear Quadratic Regulator (LQR). ELKOMIKA: Jurnal Teknik Energi Elektrik, Teknik Telekomunikasi, \& Teknik Elektronika, 72), 224.

Gulbahce, M. O., Kocabas, D. A., \& Atalay, A. K. (2013). A study to determine the act of excitation current on braking torque for a low power eddy current brake. 2013 International Electric Machines \& Drives Conference, (pp. 1321-1325).

Handaya, D., \& Fauziah, R. (2021). Proportional-Integral-Derivative and Linear Quadratic Regulator Control of Direct Current Motor Position using Multi-Turn Based on LabView. Journal of Robotics and Control (JRC), 2(4).

Houari, A., Bachir, I., Mohame, D. K., \& Mohamed, M. K. (2020). PID vs LQR controller for tilt rotor airplane. International Journal of Electrical and Computer Engineering (IJECE), $10(6), 6309$.

Isdaryani, F., Hesya, M. F. V., \& Feriyonika, F. (2021). Sintesis Kendali PID Digital dengan Diskritisasi Langsung dan Backward Difference. ELKOMIKA: Jurnal Teknik Energi Elektrik, Teknik Telekomunikasi, \& Teknik Elektronika, 9(2), 467.

Ma'arif, A., \& Setiawan, N. R. (2021). Control of DC Motor Using Integral State Feedback and Comparison with PID: Simulation and Arduino Implementation. Journal of Robotics and Control (JRC), 2(5).

Munadi, M., Pandu, R. A., Wiradinata, R., Julianti, H. P., \& Setiawan, R. (2020). Model and prototype of mobile incubator using PID controller based on Arduino Uno. Jurnal ELKOMIKA - 936 
Desain Kendali Sistem Eddy Current Brakes Dinamometer menggunakan Linear Quadratic Regulator (LQR)

Teknologi Dan Sistem Komputer, 8(1), 69-77.

Nahari, T., Joelianto, E., \& Suyatman. (2012). An eddy brakes dynamometer control system design using state space based PID controller. 2012 IEEE Conference on Control, Systems \& Industrial Informatics, (pp. 163-168).

Nunes, A. J. R., \& Brojo, F. M. R. P. (2020, June 2). Designing an Eddy Current Brake for Engine Testing. International Congress on Engineering - Engineering for Evolution.

Purnawan, H., Mardlijah, \& Purwanto, E. B. (2017). Design of linear quadratic regulator (LQR) control system for flight stability of LSU-05. Journal of Physics: Conference Series, 890, 012056.

Rao, C. S., Santosh, S., \& V, D. R. (2020). Tuning optimal PID controllers for open loop unstable first order plus time delay systems by minimizing ITAE criterion. IFACPapersOnLine, 53(1), 123-128. 